\title{
"Fascist or opportunist?": The political career of Oswald Pirow, 1915-1943
}

\section{F.A. Mouton*}

\begin{abstract}
Oswald Pirow's established place in South African historiography is that of a confirmed fascist, but in reality he was an opportunist. Raw ambition was the underlying motive for every political action he took and he had a ruthless ability to adjust his sails to prevailing political winds. He hitched his ambitions to the political momentum of influential persons such as Tielman Roos and J.B.M. Hertzog in the National Party with flattery and avowals of unquestioning loyalty. As a Roos acolyte he was an uncompromising republican, while as a Hertzog loyalist he rejected republicanism and national-socialism, and was a friend of the Jewish community. After September 1939 with the collapse of the Hertzog government and with Nazi Germany seemingly winning the Second World War, overnight he became a radical republican, a national-socialist and an anti-Semite. The essence of his political belief was not national-socialism, but winning, and the opportunistic advancement of his career. Pirow's founding of the national-socialist movement, the New Order in 1940 was a gamble that "went for broke" on a German victory.
\end{abstract}

Keywords: Oswald Pirow; New Order; fascism; Nazi Germany; opportunism; Tielman Roos; J.B.M. Hertzog; ambition; Second World War.

\section{Opsomming}

In die Suid-Afrikaanse historiografie word Oswald Pirow getipeer as 'n oortuigde fascis, maar in werklikheid was hy 'n opportunis. Rou ambisie was die onderliggende motivering van alle politieke handelinge deur hom. Hy het die onverbiddelike vermoë gehad om sy seile na heersende politieke winde te span. Pirow het sy ambisies gekoppel aan die politieke momentum van invloedryke persone soos Tielman Roos en J.B.M. Hertzog in die Nasionale Party deur vleiery en absolute lojaliteit. As 'n Roos aanhanger was hy 'n onverbiddelike republikein, maar as 'n Hertzog lojalis het hy republikanisme en nasionaal-sosialisme verwerp, en was as 'n vriend van die Joodse gemeenskap gesien. Na September 1939, met die ineenstorting van die Hertzog regering, en met Nazi Duitsland wat besig was om die Tweede Wêreldoorlog te wen, het hy oornag in 'n radikale republikein, 'n nasionaal-sosialis en 'n anti-Semiet ontpop. Die wese van sy politieke siening was nie nasionaal-sosialisme nie, maar sy ambisie om te wen, en sy loopbaan te bevorder. Pirow se stigting van die nasionaal-

\footnotetext{
* $\quad$ F.A. Mouton is on the staff of the History Department, University of South Africa, Pretoria, and is currently busy with a biographical study of Oswald Pirow. 
sosialistiese Nuwe Orde in 1940 was 'n desperate dobbelspel op 'n Duitse militêre oorwinning.

Sleutelwoorde: Oswald Pirow; New Orde; fascisme; Nazi Duitsland; opportunisme; Tielman Roos; J.B.M Hertzog; ambisie; Tweede Wêreldoorlog.

Oswald Pirow's established place in South African historiography is that of a confirmed fascist. This perception arose because of his leadership of the nationalsocialist New Order (NO) in the 1940s, and because this is the only phase of his political career (which dates back to 1915) that has been investigated thoroughly by historians. F.J. van Heerden's doctoral thesis, "Nasionaal-Sosialisme as Faktor in die Suid-Afrikaanse Politiek, 1933-1948" (1972), Patrick Furlong's, Between Crown and Swastika: The Impact of the Radical Right on the Afrikaner Nationalist Movement in the Fascist Era (1991) and Christoph Marx's, Oxwagon Sentinel: Radical Afrikaner Nationalism and the History of the Ossewabrandwag (2008) all focus on his role in Afrikaner politics as the NO leader. The entirety of Pirow's political career has been dealt with superficially in contributions such as J.J.J. Scholtz, Dictionary of South African Biography, vol. V (1987), N.G. Garson Oxford Dictionary National Biography, vol. 44 (2004), and the journalist Piet Meiring's error-riddled chapter in his Tien Politieke Leiers: Manne na aan Ons Premiers (1973).

This article argues that raw ambition, rather than any deeply held political principles, was the underlying motive for every political action by Pirow. He had a ruthless ability to cultivate powerful figures with sycophantic flattery and avowals of unquestioning loyalty, and to adjust his sails to suit prevailing political winds. Pirow's career was one of calculated opportunism, but he was willing to take risks to satisfy his political ambitions. This was evident in 1940, at a stage when his parliamentary career was at a dead end, when he gambled on a military victory by Nazi Germany with the founding of the New Order (NO).

Pirow was born in Aberdeen in the Cape Colony on 14 August 1890. His parents were German born. His father, Carl Ferdinand a medical doctor, was the son of a missionary, and emigrated to South Africa in 1888. When Pirow was three years of age his parents settled in Potchefstroom in the Transvaal where they became naturalised citizens of the South African Republic. In 1905, due to a lack of educational facilities in South Africa, Pirow went to study at Itzehoe Gymnasium in Holstein, Germany. On the completion of his school education he attended the Middle Temple in London from 1910 to qualify as a barrister. When called to the Bar he returned to South Africa in 1914. Pirow was determined to make his mark as an advocate, and to pursue a political career. He had a driven personality and always had to be at the forefront and the top of whatever he did. He was, for example, an outstanding swimmer, who won his event at the London swimming championship. As 
a javelin thrower he was the British champion in 1913. ${ }^{1}$ In his final Bar examination in 1913 he was placed first, and was awarded a certificate of honour. ${ }^{2}$

Pirow claimed that on his return to South Africa he immediately associated himself with the Afrikaner nationalism of General J.B.M. Hertzog, and the newly founded National Party (NP) to campaign for Afrikaner interests. Very little is known about his early years back in South Africa, ${ }^{3}$ but in 1914 the NP was an insignificant splinter party compared to the ruling South African Party (SAP) of generals Louis Botha and Jan Smuts. It is thus doubtful that Pirow viewed the NP as a suitable vehicle for his ambitions. He therefore decided to join the Union Defence Force (UDF) with the outbreak of the First World War in August 1914. As an NP supporter he would not have done so because the party vehemently opposed any involvement in the war. In fact, more than 11000 Afrikaners resorted to armed rebellion against the decision to fight for the British Empire, while many more deserted the SAP to join the NP.

Against this background, the fact that Pirow had joined the UDF was a potential source of embarrassment for his legal and political ambitions. Already in the 1915 general election he had contested a parliamentary seat on behalf of the NP without success. To cover up his error of judgement he created a convenient narrative that he had joined the UDF as an attempt to support the rebels. He claimed that he would have joined the rebel forces had it not been that on 15 September 1914 General Koos de la Rey was accidently shot by the police while driving to the UDF military base in Potchefstroom. According to Pirow, the South African War hero intended to hoist the old South African Republican flag at the local military base, and to march with these UDF units to Pretoria. He furthermore maintained that he and other officers attended the memorial service for De la Rey at Lichtenburg on 20 September and that they wanted to arrest Botha and Smuts, but that General C. Beyers, commander-in-chief of the UDF, on hearing of the plan, forbade it. Pirow then left the UDF because he refused to participate in the suppression of the rebellion. ${ }^{4}$

Fortunately for Pirow, no one ever checked his military record. He was attached to the Potchefstroom Ruiters (11th Mounted Rifles) as a lieutenant, but only for the period from 24 October and 20 December $1914 .{ }^{5}$ He thus joined the unit a month after the death of De la Rey, and a week before the first shot of the rebellion was fired in the Transvaal - and then left his unit after the rebellion was crushed in

1. Rand Daily Mail, 3 July 1930.

2. Correspondence with Megan Dunmall, assistant archivist, Honourable Society of the Middle Temple, 22 August 2016.

3. The Oswald Pirow Collection at the University of the Free State's (hereafter UFS) Archive for Contemporary Affairs (hereafter ACA) consists mainly of undated newspaper clippings.

4. $\quad$ 0. Pirow, James Barry Munnik Hertzog (George Allen \& Unwin, London, 1957), p 70; Die Brandwag, 18 December 1953; Debatte van die Volksraad, 12 June 1939, col. 6820.

5. Correspondence with G.W. Prinsloo, archivist at the SANDF Documentation Centre, 20 December 2016. 
the Transvaal. Why he left the UDF on that date is unknown, but what is clear is that he was certainly not a member of the NP when he volunteered his military services. Pirow's attempt to cover up his role in the UDF is an example of how he was prone to adapt the truth to suit his own purposes. This propensity is also reflected in his unreliable memoirs published as Die Nuwe Orde between 1945 and 1946, and his biography of Hertzog (1957), both of which tend to glorify his own role.

The biggest handicap for Pirow's legal and political ambitions was not his involvement in the UDF, but the perception that he was a German. His background, education and especially the fact that his home language was German, and that he was a member of the Lutheran Church, meant that Afrikaners felt that he was not one them. There was a feeling that he had a German mentality, ${ }^{6}$ and Afrikaner cultural organisations kept their distance. ${ }^{7}$ In climbing the greasy pole of success in politics Pirow thus lacked the usual support system of school, university, cultural organisations and the church, all of which were available for any an ambitious young Afrikaner. To compensate for this lack of support he needed a powerful backer to advance his career, and he found one in Tielman Roos, leader of the NP in the Transvaal, and the most outstanding and sought-after advocate at the Pretoria Bar. ${ }^{8}$ Pirow, who could use charm to get what he wanted, set out to cultivate this friendship. Roos, despite his jovial and successful image, was very sensitive to criticism and highly susceptible to acknowledgement and praise. ${ }^{9}$ Pirow was more than willing to provide praise and support. In exchange, Roos would go to almost any lengths to assist a friend. ${ }^{10}$

Their friendship seemed odd to many observers because Roos was amiable, kind, generous to those in need, easy-going, and witty. Pirow, in sharp contrast, was short tempered, snide, had no sense of humour at all, and was utterly self-centred. ${ }^{11}$ With Roos's patronage, combined with his own ability, drive and energy, Pirow had a meteoric rise at the Pretoria Bar. He also owed his political career to Roos. As at the Bar, they were inseparable at political meetings, often addressing the public from the same platform. Pirow's powers as an orator, combined with his combative personality, made him an effective politician. Roos reciprocated by turning Pirow into a high profiled figure in the party. In 1917 the politically ambitious Pirow became a member of the Transvaal Provincial Council, and in 1924 he was elected to parliament. In this election the NP was swept into power.

\footnotetext{
6. D. and J. De Villiers, Paul Sauer (Tafelberg, Cape Town, 1977), p 76.

7. P. Meiring, Tien Politieke Leiers: Manne na aan Ons Premiers (Tafelberg, Cape Town, 1973), pp 92, 95.

8. J. Brits, Tielman Roos: Political Prophet or Opportunist? (Unisa Press, Pretoria, 1987), pp 3, 17-20, 26-32.

9. J.P. Brits, "Tielman Roos se Rol in die Suid-Afrikaanse Politiek, 1907-1935", (Unpublished D. Phil, Unisa, 1977), pp 170, 478.

10. C.P. Bresler, Lineage of Conflict: A South African Miscellany (Afrikaanse Pers Boeke, Johannesburg, 1952), p 149.

11. L. Blackwell, African Occasions: Reminiscences of Thirty Years of Bar, Bench, and Politics in South Africa (Hutchinson \& Co, London, 1938), p 156.
} 
In the Westminster parliamentary system, newly-elected parliamentarians of governing parties are expected to attend parliamentary debates, to praise and support the government and to harass the opposing party. However, Pirow was no ordinary backbencher. As the Cape Times (24 January 1930) mockingly put it, he was "the chosen pet of Mr. Roos", and with the patronage of the second most powerful man in the NP, Pirow did not feel obliged to follow the rules. Bored with the life of a backbencher he hardly ever attended parliamentary debates; instead he focused on his burgeoning legal career. When Roos was appointed Minister of Justice in 1924, Pirow was there to take over Roos's practice, and Pirow's stature increased yet again when he took silk as a King's Council in $1925 .{ }^{12}$ His loyalty was furthermore not to the NP and Hertzog, but to Roos whom he was confident would become the prime minister, and had promised him a place in his cabinet. ${ }^{13}$ By hitching his ambitions to Roos's political wagon, and aware of his mentor's extreme sensitivity to criticism from within the NP,14 Pirow was obliged to support Roos in his vindictive power struggle with Dr D.F. Malan, the Minister of Health, Interior and Education, and the leader of the Cape NP - Roos's only serious rival as a possible successor to Hertzog. ${ }^{15}$ Acting as Roos's enforcer, Pirow set out to demolish Malan's reputation as an efficient and capable minister. In an interview with Ons Vaderland in late 1925, he attacked Malan's competence in no uncertain terms. The SAP supporting newspapers published these accusations with glee. Malan did not take kindly to this. A.L. Geyer, editor of Die Burger and a Malan admirer, came to his aid and publicly condemned Pirow's behaviour. ${ }^{16}$ Pirow had made powerful and dangerous enemies in Malan and Geyer.

Pirow's relationship with Hertzog was also stretched to breaking point with his support of Roos on Article 4 of the NP's constitution which embodied the party's support for the ideal of secession from the British Empire. After the Balfour Declaration of 1926 had secured South Africa's and the other British dominions' equal status with Britain, the prime minister felt that as South Africa was a sovereign nation within the British Empire the issue of republicanism should be shelved. However, Roos wanted to retain Article 4 as an ideal in the NP. ${ }^{17}$ Again it was Pirow who stepped up. At a public meeting in December 1927, Pirow stated forcefully that the ideal of a republic should always be a pillar of the NP's principles. ${ }^{18}$ For this he was

12. UFS ACA, Oswald Pirow Collection, File 7, Newspaper clipping of the South Africa, 13 June 1936.

13. O. Pirow, "Drie Manne uit die Dae van Samesmelting: Hetzog, Smuts en Tielman Roos", Die Huisgenoot, 5 December 1952, p 8.

14. *Brits, “Tielman Roos se Rol”, pp 219-220.

15. L. Korf, “D.F. Malan: A Political Biography' (Unpublished D. Phil thesis, University of Stellenbosch, 2010), p 271.

16. Die Burger, 13, 15, 16 and 25 January 1926.

17. Brits, Tielman Roos, pp 133-.135.

18. Cape Times, 23 December 1927. 
publicly reprimanded by the prime minister; Hertzog made it clear that Pirow's uncompromising stance could harm the NP.19

By early 1928, Pirow realised that Roos's political star was fading fast. His mentor's chances of becoming prime minister became increasingly remote as his bored, irresponsible, cynical attitude to state affairs, and his neglect of his portfolio, had alienated Hertzog and the rest of the cabinet. In addition, Roos was battling poor health and had lost interest in politics. ${ }^{20}$ Pirow was not one to allow acolyte entrapment to harm his political ambition. Realising that he had hitched his wagon to a doomed political star, Pirow changed tack and began to reach out to the prime minister. Hertzog, an autocratic party leader, was obsessive about loyalty; he only promoted those whom he felt were 100 per cent loyal to him. What made it possible for Pirow to reach out to the prime minister was his susceptibility to flattery ${ }^{21}$ and accordingly, Pirow set out to cultivate Hertzog's friendship. His legal expertise also counted in Pirow's favour and he volunteered his services to Hertzog in dealing with constitutional matters. They spent many hours together in drawing up a constitution for the mandated territory of South West Africa, and compiling a Bill to remove blacks from the common voters' roll in the Cape Province. ${ }^{22}$ In the process, conveniently, Pirow's once strident republicanism evaporated. By March 1929, Pirow was part of Hertzog's inner circle. ${ }^{23}$

Pirow's status as a Hertzog favourite led to his appointment in June 1929 as the new Minister of Justice when Roos resigned for health reasons. (Roos's loyal acolytes were not so lucky as without the protection of their leader they were marginalised in the party. ${ }^{24}$ ) Pirow's appointment at the age of 38 made him, at that stage, the youngest cabinet minister South Africa had ever had, which raised some eyebrows in and outside of the NP, especially because had no proven track record as a parliamentarian. He was such an absentee member that according to Leslie Blackwell, an SAP MP, he was virtually unknown in the House of Assembly in 1929.25 In a leading article in Die Burger (19 June 1929) an unimpressed Geyer pointed out that Pirow had no parliamentary success behind him, but conceded that he was very intelligent.

By appointing Roos in November 1929 to the Appeal Court in Bloemfontein, Pirow felt that he had repaid his debt to his old mentor. ${ }^{26}$ They subsequently began to

19. J.H. le Roux en P.W. Coetzer, Die Nasionale Party, Vol. 3, Die Eerste Bewindsjare, 19241934 (INEG, Bloemfontein, 1982), pp 138-139.

20. Brits, “Tielman Roos se Rol”, p 219.

21. Western Cape Provincial Archives and Records Service (hereafter WCPA), A.L. Geyer Collection, vol. 3, Political notebook, 20 February 1934.

22. Pirow, "Drie Manne uit die Dae van Samesmelting", pp 9-11.

23. National Archives, Pretoria (hereafter NA Pretoria), J.B.M Hertzog Papers, vol. 95, Pirow - Hertzog, 15 March 1929.

24. H. Reitz, The Conversion of a South African Nationalist (Unie-Volkspers, Cape Town, 1946), pp 129-130.

25. $\quad$ Blackwell, African Occasions, p 156.

26. Pirow, "Drie Manne uit die Dae van Samesmelting", p 8. 
drift apart while a father-son relationship developed between Pirow and Hertzog. They went on walks together and Pirow became a regular house guest. He became someone to share problems with, or just to discuss a book he had read. Pirow also endeared himself to the prime minister by showing himself to be a competent and energetic minister, bursting with ideas and energy. An aging Hertzog became increasingly dependent on him. ${ }^{27}$ Pirow's loyalty to Hertzog was reflected on 21 December 1932, a time when the Great Depression was crippling South Africa's economy, when Roos announced his resignation as a judge and his return to politics to bring about a coalition government and the devaluation of the South African pound to save the country. Roos's dramatic return to politics unleashed a political storm, the English-medium press portraying him as the messiah who would topple the government, and would save the country from its economic despair. His former acolytes rushed to join him. Pirow was careful to keep his distance because he knew that with the NP and its supporting press condemning Roos as a political traitor, and without a formal party structure behind him, his former mentor was doomed to disaster. Joining him would be political suicide. To the outrage of Roos, Pirow became part of the chorus that condemned him as a traitor. ${ }^{28}$

Hertzog was under immense pressure with Roos's return, and decided to abandon the gold standard on 27 December 1932. In the wake of these dramatic events, Smuts reached out to Hertzog in a parliamentary motion on 24 January 1933 that he should resign and form a coalition government with the SAP to resolve the economic crisis. When Hertzog told a stunned Pirow that the state of the country made cooperation with the leader of the opposition necessary, Pirow gave his full, unquestionable support to the prime minister. Acting as Hertzog's enforcer, a role he knew all too well, the methods Pirow used to encourage support for a coalition among reluctant NP MPs comprised a combination of intimidation, flattery and lies; he created lifelong enemies among them, and even the perception that he was not a true Afrikaner. ${ }^{29}$

The coalition government was sworn in on 31 March and Pirow's loyalty to Hertzog was rewarded with his promotion to the more senior position as the Minister of Railways and Harbours, as well as that of Defence. To secure legitimacy for the coalition government a general election was promptly announced for 17 May with the NP and SAP not opposing each other. Pirow played a leading role in the election campaign against Roos who contested the election with a motley group of followers. By April 1933, Roos was a political wreck, broken in spirit. Overnight his popularity had evaporated. The English-medium press that had hailed him breathlessly as the saviour of South Africa dropped him with alacrity when the coalition government was formed. This left Roos, who was battling poor health, politically isolated and in a desperate financial situation. There was no need for Pirow to campaign against Roos who was contesting the Rustenburg constituency, because he was no threat to the

27. Pirow, James Barry Munnik Hertzog, pp 136-138, 216.

28. Cape Times, 11 February 1933.

29. J.L. Basson, J.G. Strijdom: Sy Politieke Loopbaan van 1929 tot 1948 (Wonderboomuitgewers, Pretoria, 1980), pp 44-46. 
NP. ${ }^{30}$ But Pirow, determined to showcase his loyalty to Hertzog, made a point of addressing a meeting in Rustenburg. ${ }^{31}$ In effect he was kicking a down-and-out Roos, and many viewed this treatment of his former mentor as ruthless. ${ }^{32}$ Roos took it badly and he condemned Pirow as daardie klein Hitler (that little Hitler). ${ }^{33}$ On election day Roos suffered a crushing defeat, and he died in 1935, an impoverished and broken man. Pirow did not attend the funeral of the man to whom he owed his legal and political career, leaving many of his former fellow Roos disciples disgusted with him, turning them into lifelong enemies. ${ }^{34}$

Pirow was a dynamic and innovative minister. He modernised the railway system, founded the South African Airways, and to some extent revitalised a ramshackle UDF. His successes fuelled speculation that he would succeed Hertzog as prime minister. To achieve this ambition, Pirow set out to cultivate English-speaking SAP MPs who until 1933 had viewed him as self-advertising, egotist, always trying to override the opposition in a dictatorial way. ${ }^{35}$ He overwhelmed them with his charm. For Pirow, charm was a weapon he could turn on and off on a need-to-use basis. M.E. Antrobus, a member of the British High Commissioner's staff in South Africa, explained Pirow's tactics in the following terms, "... he [Pirow] is charming when he is getting something he wants but viperish and entirely outspoken when he isn't". ${ }^{36}$ It was difficult to resist his charm if he wanted to secure an individual's friendship, as was evident in his wooing of C.F. Stallard, the leader of the pro-imperial Dominion Party (DP), one of his severest critics in parliament. Pirow went to extreme measures to win him over. In 1936 he went so far as to arrange that a South African Air Force plane fly Stallard to Cairo to meet him on his return from a British visit to discuss defence matters. ${ }^{37}$ Stallard's correspondence reflects that he loved every second of the flight, as well as his stay in Cairo. Before long, they became close personal friends, ${ }^{38}$ and the DP's criticism was toned down. According to B.K. Long, a prominent English-speaking MP, Pirow was a mixer, happy to "gather a little crowd around him, stand them drinks, tell them stories and be on genial, hail-fellow-well-met terms with them". Furthermore, although Long was an outspoken critic of Nazi Germany, he did not detect any national-socialist sympathies in the jovial Pirow. ${ }^{39}$

30. Brits, Tielman Roos., pp 204-209.

31. Rand Daily Mail, 9 May 1933.

32. Bresler, Lineage of Conflict, p 149; Reitz, Conversion of a South African Nationalist, pp 88-89.

33. Die Volksblad, 13 April 1933.

34. Die Burger, 9 August 1935.

35. UK National Archives, Kew (hereafter NA Kew), DO 35,334/1, High Commissioner's despatch, 22 August 1933.

36. NA Kew, Avia 2/1879, File 29827/Part IV, M.E. Antrobus - C.G.K. Syers, 25 March 1936.

37. NA Kew, D0 35/335/1, Letter from the High Commissioner's office - Dominion Office, 17 July 1936.

38. Unisa, UP Archive, C.F. Stallard Papers, Correspondence July to September 1936, Stallard - Pirow, 20 July 1936, 7 and 23 September 1936; Correspondence October to December 1936, Stallard - Pirow, 20 November1936.

39. B.K. Long, In Smuts's Camp (OUP, London, 1945) pp 67 - 68. 
Pirow was seen increasingly by English-speakers as a figure free of the rivalries that existed between English-speakers and Afrikaners since the South African War, ${ }^{40}$ especially as he made it clear that republicanism was not practical politics. ${ }^{41}$ His relentless pounding of the NP added to his popularity in the Englishspeaking community. On 5 December 1934 the SAP and NP merged to create the United Party (UP), popularly known as the Fusion government. Malan refused to join the new party and became the leader of the remaining rump of the NP. This ultranationalistic party became popularly known as the Purified NP. The purifieds, with messianic fervour, set out to turn South Africa into a republic. Pirow, a master of sarcasm and viciousness, was adept at belittling and wounding his opponents in debates. He mocked the NP MPs contemptuously, labelling them as backward and accusing them of being brainless hypocrites. These personal attacks made him a hated person amongst the purifieds and in Die Burger (15 May 1936) Geyer warned that in the future there would come a day of reckoning; Pirow would have to account for his abusive behaviour. J.G Strijdom, NP MP for Waterberg, never forgave Pirow for the contempt he heaped upon him in the House of Assembly, especially when Pirow had the audacity to mock him and call him a mere small-town lawyer. ${ }^{42}$

Pirow also went on a charm offensive with English-speaking journalists. Apart from respecting him as an extraordinarily capable man they enjoyed his accessible, affable and stimulating personality, and more importantly, Pirow's blithe willingness to share confidential information in off-the-record conversations. This made him the blue-eyed boy of the English-medium newspapers. ${ }^{43}$ One editor began a leading article "we do not like Mr Pirow - we respect him!". ${ }^{4}$ Hoping to secure Pirow as prime minister, journalists went out of their way to build-up his reputation and to defend him against accusations that he had fascist tendencies.

In June 1935, Pirow made two speeches in Johannesburg about the economic challenges facing the country. Although he made it clear that he did not propose a society based on fascist corporations, he did advocate stronger governmental involvement in commerce, and a system based along corporative lines. He suggested that what worked well in the professions could work equally well in every other sphere of national activity. He pointed out the advantages of what he termed "ordered self-government among all sections of the economic system", especially to assist the economically hard-pressed middle class. But some commentators reacted negatively. Morris Kentridge, a fellow UP MP, condemned the idea as a fascist inspired system. This led to the Pretoria News of 18 June 1935 carrying a leading article entitled "Is Mr Pirow a Fascist?" The paper answered with a resounding "no". For the Pretoria News,

40. UFS ACA, Oswald Pirow Collection, File 7, Unidentified newspaper clipping dated 10 June 1936.

41. NA Kew, DO 35/334/2, High Commissioner's despatch, 30 October 1934.

42. B. Schoeman, My Lewe in die Politiek (Perskor, Johannesburg, 1978), pp 47, 49.

43. W.A. Bellwood, South African Backdrop (Nasionale Boekhandel, Cape Town, 1969), p 57.

44. G.H. Calpin, There are No South Africans (Thomson Nelson \& Sons, London, 1941), p 260. 
Pirow's stance on order and discipline, as well as his ideas on social reconstruction based on economic progress, shared alike by the state and private enterprise, were interesting. In a leading article of 20 June, the editor reflected the attitude of Pirow admirers that he was an energetic and dynamic minister who was attempting to resolve the country's economic woes in a period of worldwide chaos. After all, it suggested, the old economic textbook had become out of date. But the Rand Daily Mail of 22 June 1935 was wary; it rejected Pirow's economic plans as too simplistic, drastic and even dangerous, but at the same time stated clearly that his idea of a group association was not fascist inspired. The newspaper furthermore declared its admiration for Pirow's energy and his reputation for getting things done. ${ }^{45}$

The accusations of fascism also fell flat because Pirow's suggestions reflected no anti-Semitic tendencies. He was in fact seen as a friend of the Jewish community. In December 1932 he campaigned diligently for the NP's Jewish candidate, H.J. Schlosberg, in the Germiston by-election. ${ }^{46}$ Confronted by extreme right-wingers on the alleged economic influence of Jews he made it clear that he was opposed to blaming poverty on the Jews, and stated that he refused to judge a person on the basis of his religion. ${ }^{47}$ To Sarah Gertrude Millin, a prominent Jewish author who wrote to him in 1934 on the rise of anti-Semitism in South Africa, he responded that he viewed the persecution of Jews "as cowardly and despicable". ${ }^{48}$ During the 1938 general election, at a hostile public meeting in Braamfontein in Johannesburg, he was challenged on his stance to the "Jewish problem" in the country. Pirow promptly denied the existence of any such problem. ${ }^{49}$ For H.F. Verwoerd, editor of the NP supporting Die Transvaler, Pirow's comfortable victory in his Gezina constituency, was made possible by the support of Jewish financial power which provided his campaign with cars to convey voters to the polling booth. ${ }^{50}$ The strength of the perception that Pirow supported the Jewish community, was reflected in the arrest of one Stanislow Boleslow Gricius, a blacksmith of Clocolan, on a charge of criminal libel in August 1939. Gricius had distributed a letter to the effect that Pirow was a Jew, that his real name was Shapirow, and that he was using his position as a cabinet minister to assist Jews to avoid paying tax. ${ }^{51}$

Furthermore, Pirow was outspoken in his support of democracy, and his rejection of fascism. On 6 June 1937 he stated emphatically: "South Africa will never depart from its democratic system, and it will be deplorable, therefore, if that system is undermined or rendered impotent."52 In January 1938 at a public meeting in Piet

45. NA Kew, DO 35/334/3, High Commissioner's despatch, 25 June 1935.

46. Die Volksblad, 7 November 1932.

47. M. Shain, A Perfect Storm: Antisemitism in South Africa, 1930-1948 (Jonathan Ball, Johannesburg, 2015), pp 9, 92.

48. University of the Witwatersrand (hereafter Wits), S.G. Millin Papers, C1, Pirow Millin, 7 February 1934.

49. Die Transvaler, 13 April 1938.

50. Die Transvaler, 19 and 20 May 1938.

51. Cape Times, 16 August 1939.

52. Calpin, There are No South Africans, p 391. 
Retief he made it clear that the importation of Nazism into South Africa would lead to civil war within four weeks, and that South Africa's democratic system could be improved, but not by introducing "foreign" systems. ${ }^{53}$ That he was not remotely seen as pro-German, or sympathetic to fascism, and that it was just a matter of time before he became prime minister, was evident in a letter Lord Claredon, the governorgeneral in South Africa, wrote to king Edward VIII in May 1936:

He is a very able little man and, although a German by birth and a Republican at heart, is sound from an Imperial point of view... He has however to contend with political difficulties here in so far as many Imperial questions are concerned, but is none the less anxious and ready to co-operate: indeed, his courage and determination have enabled him to go further than many of us thought it possible. Sooner or later he will undoubtedly become Prime Minister of the Union: he is therefore well worth taking notice of ...54

Personally, Pirow felt assured that the premiership was within his grasp; he knew that Hertzog was determined that Smuts should not be his successor. ${ }^{55}$

The perception of Pirow as a leading statesman, friend of the British Empire and a defender of democracy, was bolstered by his mission to Hitler in November 1938. The meeting was part of an official visit to Britain to negotiate with the British War Office about military supplies for the UDF, and was motivated by his desire to become prime minister. He was desperate to avoid a European war involving Britain because he knew it would be difficult for South Africa to remain neutral, and such a war could destroy the Fusion government and his prime ministerial ambitions. He thus offered his services to Neville Chamberlain, the British prime minister, to act as a mediator with Hitler to prevent a war. In London, after meeting with Captain V.A. Cazalet, a British parliamentarian passionately concerned about the plight of Jewish refugees, Pirow became convinced that settling the Jewish question was the only way to avoid a seemingly inevitable war in Europe. ${ }^{56}$ A solution was the possible resettlement of German Jews in a new national home, possibly Tanganyika, Madagascar or British Guinea. Because German Jews were only allowed to leave Germany with very little by way of possessions, Hitler had to be persuaded to permit them to take one half of their property when they emigrated. International aid could provide Jews with the other half. Pirow undertook to discuss this option, against the background of a general colonial settlement, with the French and German governments. According to Pirow, Chamberlain was satisfied with his offer to act as an unofficial mediator between Britain and Germany. ${ }^{57}$

53. Cape Times, 31 January 1938.

54. Royal Archives, Windsor, PS/GVI/C 051, The Earl of Clarendon - King Edward VIII, 1936, 001; Clarendon to Edward VIII, 28 May 1936, p 6. (I am grateful to John Lambert for this document.)

55. Pirow, James Barry Munnik Hertzog, p 155.

56. Unisa, United Party Archives, Louis Esselen Papers, Pirow - L. Esselen, 22 November 1938.

57. Die Nuwe Orde, 24 January 1946. 
In the 1940s Pirow created the perception that his conversion to nationalsocialism, and the desire that South Africa should remain neutral in a war between Germany and Britain, was the outcome of his meetings and his admiration for fascist leaders such as Dr Antonio Salazar, the Portuguese dictator, General Francisco Franco, leader of the Spanish nationalist government in the civil war, Hitler and Benito Mussolini of Italy, and the military might of Germany. ${ }^{58}$ These proclamations of admiration for Nazi Germany and fascism were so convincing that after the German surrender in 1945, Brigadier R.J. Palmer, commissioner of the South African Police, requested British military intelligence to determine if any evidence of contact between Pirow and Nazi Germany could be found in captured documentation. British intelligence found no such incriminating documentation. ${ }^{59}$ The reason for this was that until 1940 Pirow had no admiration for fascism or its leaders, and was adamant that South Africa would eventually enter a war against Germany after a short period of neutrality.

After meeting Salazar, Pirow had a confidential conversation in Lisbon with David Friedmann, a South African journalist with whom he had a close relationship, in which he expressed his serious reservations about the oppressive nature of Salazar's fascist regime.60 Friedmann's notes reflect no admiration at all for Franco by Pirow, only his profound shock at the horror which defenceless civilians had to endure from aerial bombardment in the civil war.61 Pirow also left Hitler unimpressed after meeting him on 24 November 1938 at Berchtesgaden. ${ }^{62}$ A British diplomat in Berlin, Sir Ogilvie Forbes, reported that Pirow had suggested to him that talking to Hitler was like talking to a brick wall; in their meeting, he said, it was as if Hitler was addressing ten thousand people. He also claimed that Hitler occasionally thumped the table, and that he, Pirow, thumped the table back. ${ }^{63}$ He later related to Lord Perth, the British ambassador in Italy, that talking to Hitler was like being up against a "stone wall". ${ }^{4}$ Furthermore, Pirow, in a meeting with Hermann Göring, head of the German air force and Hitler's deputy, made it clear that that in a war between Germany and Britain, South Africa would not enter the war at once, but a government which did not take South Africa into the war would struggle to survive, and that within six months the country would be fighting on the side of Britain. He added that South Africa would be part of the British Empire for the next hundred years or so.65 Pirow conveyed a similar message to Mussolini, emphasising that South Africa was a loyal member of

58. Die Nuwe Orde, 4 October 1945, 2; 30 May, 12; and 26 September 1946.

59. NA Kew, KV 2/908, Brigadier Sir David Petrie -Brigadier R.J. Palmer, 5 September 1945.

60. Wits, D. Friedmann Papers, Vol. 1, Unpublished memoirs, pp 47-48, 60, 62.

61. Wits, D. Friedmann Papers, Vol. 1, Unpublished memoirs, pp 48-49

62. W. van der Merwe, "Suid-Afrika en 'appeasement': Oswald Pirow se 'vredesending' na Nazi-Duitsland in November 1938", Kleio, 20, 1988, pp 46-49; Wits, D. Friedmann Papers, Vol. 1, Unpublished memoirs which include the German memorandum of the meeting, pp 76-2.

63. NA Kew, F0 371/21791, Report by Sir Ogilvie Forbes, 26 November 1938.

64. NA Kew, FO 371/21791, Report by Lord Perth, 28 November 1938.

65. NA Kew, FO 371/21791, Report by Malcolm MacDonald, 5 December 1938. 
the British Empire, and that South Africa would eventually join any war against Germany after a period of neutrality. ${ }^{66}$ That Pirow was not seen as pro-German, or a fascist sympathiser, was evident in Berlin instructing its diplomatic representative in South Africa, Dr Rudolf Leitner, not to make any special effort for Pirow in the Reichsparteitag of $1939 .{ }^{67}$

Pirow's visit to Britain and Germany confirmed to the British establishment that he was indeed a trusted ally. ${ }^{68}$ This was evident in an article by S. Hardie Stewart, editor of The Torchbearer, the official mouthpiece of the Junior Imperial League, published in the Right Bulletin, organ of the Right Book Club. Here Stewart emphasises that if Pirow were to be the next prime minister of South Africa this would be advantageous for both South Africa and Britain: "Mr Pirow is a true British subject. His interests are those of the British Commonwealth of Nations." 69 Back in South Africa, Pirow reinforced his anti-fascist credentials. On several occasions he told his close friend, Piet van der Byl, MP for Bredasdorp, that he thought Hitler was a "bloody lunatic"; ${ }^{70}$ and on 4 March 1939 in Stellenbosch, he stated forcefully that after his European visit he was more convinced than ever that a dictatorship would never succeed in South Africa. ${ }^{71}$ Furthermore, when Hitler invaded and occupied Czechoslovakia on 15 March 1939 he told W.A. Bellwood of The Star that the German dictator "must have gone thoroughly mad". ${ }^{72}$ Pirow also bolstered his reputation as a defender of democracy in his attitude towards the Ossewa-Brandwag (OB) which was formed in 1938 as an Afrikaner cultural organisation after the centenary celebration of the Great Trek. However, the OB evolved rapidly into a militant pro-German paramilitary movement and in his capacity as Minister of Defence in May 1939, Pirow banned all Active Citizen Force (ACF) and commando officers from joining the $\mathrm{OB}$ because of its militaristic nature. ${ }^{73}$

On 1 September 1939, Germany invaded Poland, leading to an ultimatum by Britain and France for Germany to withdraw from Polish territory, failing which they would declare war on 3 September. In discussing the situation in Europe, Pirow confided in T.C. Robertson of the Sunday Times that it would take at least six months before a decision would be made to enter the war. ${ }^{74}$ However, this was before he knew that Smuts was insisting that South Africa enter the war immediately. Pirow, realising that this would lead to a split in the UP and the end of the Fusion government, was confident that with the support of the NP the neutrality vote would

66. NA Kew, FO 371/21791, Report by Lord Perth, 28 November 1938.

67. Van der Merwe, "Suid-Afrika en 'appeasement", p 53.

68. R. Ovendale, "Appeasement" and the English-speaking World: Britain, the United States, the Dominions and the Policy of "Appeasement", 1937-1939 (University of Wales Press, Cardiff, 1975), p 193.

69. Sunday Times, 26 February 1939.

70. P. van der Byl, Top Hat to Velskoen (Howard Timmins, Cape Town, 1973), p 139.

71. Die Burger, 6 March 1939.

72. Bellwood, South African Backdrop, p 60.

73. Die Suiderstem, 8 May 1939.

74. Dagbreek en Sondagnuus, 6 September 1964. 
prevail in the House of Assembly, leading to a realignment of political parties. Once again, Pirow showed his remarkable ability to adapt his politics to prevailing circumstances. The evening of 3 September, Hertzog requested that Malan, as leader of the NP, should come to see him at his official residence to explain the situation to him. Pirow, who was present at this meeting, behaved as if the events of the last six years had never happened, proclaiming himself an ardent republican. ${ }^{75}$ To Pirow's surprise the pro-war vote won, splitting the UP, and ending his career as a government minister. After the bitter clashes between 1933 and 1939 it was difficult for Hertzog's followers to form a united party with the NP. That Pirow had overnight become a passionate republican bolstered Strijdom's loathing for Pirow and confirmed that he was a man completely without principles. ${ }^{76}$ On 9 September 1939 Geyer recorded in his political notebook his joy and satisfaction that fusion had collapsed, and that Afrikaner unity had been restored, but he also expressed his concern about Pirow's presence, describing him as “... Pirow, whose [prime] interest in politics is the advancement of the political interests of Oswald Pirow [translated]."77

In January 1940 the Hertzog group and the NP merged to form the Herenigde Nasionale Party (HNP), with Hertzog as the leader. ${ }^{78}$ And yet, Pirow felt vulnerable in the new party. Hertzog was old and exhausted, and it was obvious to all that he had reached the end of the political road. For the first time since 1915, Pirow was without a powerful backer to support and protect him. This left him isolated in the HNP, and at the mercy of former purifieds. This tenuous situation was aggravated by the destruction of his parliamentary reputation. In January 1940 with the opening of the new parliamentary session he received a hostile reception. Many of his former close allies and friends in the UP felt that he had them for fools. They treated him with icy disdain, and bitter enmity. ${ }^{79}$ On 14 March 1940 Smuts savaged Pirow's tenure mercilessly as Minister of Defence. He had done much to modernise the UDF, but despite his best efforts the army was in no state to fight in a worldwide war. Perhaps the most damaging blow came in an interjection from an UP MP that at least the UDF had its "bush carts". In the aftermath of Germany's destruction of the Polish army with its blitzkrieg tactic, Pirow's bush cart strategy seemed comical. (The bush carts, the brainchild of Pirow, were a type of Scotch cart with one shaft and two large spoked wheels pulled by two oxen or mules, to convey material over rough terrain for bush warfare in sub-tropical Africa.) The prime minister had turned Pirow into a figure of derision. ${ }^{80}$ After years of being humiliated by Pirow, former NP MPs relished the hatchet job carried out on him. ${ }^{81}$ Pirow found the obvious pleasure which these

75. A. van Wyk, Vyf Dae: Oorlogskrisis in 1939 - 'n Spanningsverhaal uit SA se Geskiedenis (Tafelberg, Cape Town, 1985), pp 78-79.

76. UFS ACA, C.R. Swart Collection, File 3/1/22, Strijdom - Swart, 8 September 1939.

77. WCPA, A.L. Geyer Collection, vol. 3, Political notebook, 9 September 1939.

78. WCPA, A.L. Geyer collection, vol. 3, Political notebook, 22 and 28 January 1940.

79. Long, In Smuts's Camp, 67-68.

80. Schoeman, My Lewe in die Politiek, p 63; Debates of the House of Assembly, 14 March 1940, col. 3436-3440.

81. UFS ACA, C.R. Swart Collection, File 3/1/27, Sauer - Swart, 14 March 1940. 
MPs derived from his savaging far more painful than the attack itself. ${ }^{82}$ Overnight he had been reduced from a feared gladiator into a pathetic, even comical, figure. ${ }^{83}$

Marginalised in the HNP and with his parliamentary reputation utterly destroyed, a desperate Pirow resorted to his favourite political strategy, which was to link up with the momentum of a prevailing political winner. Accordingly, he hitched his ambitions to the seemingly unstoppable military might of Nazi Germany. After the collapse of France in June 1940 when the defeat of an isolated Britain seemed inevitable, he started to embrace national-socialism and anti-Semitism. Pirow gambled his career on a German military victory with the founding of the nationalsocialist New Order for South Africa on 25 September 1940, a study group within the HNP. In a lengthy and widely distributed booklet, Nuwe Orde vir Suid-Afrika, he claimed that the old order of imperialist-controlled, capitalist-dominated parliamentary democracy, the source of all sorrow and pain in South Africa, was finished, a dead letter. The Afrikaner had to follow the example of the "bright new order" which had emerged in Germany, Italy, Spain and Portugal, namely an authoritarian political system based on state authority and the discipline of the people. He claimed that ultimate control of South Africa was the prerogative of the Afrikaner; all ties with the British Empire had to be severed and anti-national, unnational and unassimilable elements had to be excluded. Jews would be forbidden to enter South Africa. All Jews who had entered the country after 4 August 1914 would be regarded as illegal immigrants with no right to residence. ${ }^{84}$ With the founding of the NO Pirow also changed his attitude to the OB, expressing the hope that in future the increasingly militant organisation would provide the storm troopers of Afrikanerdom. ${ }^{85}$

The leadership of the HNP was stunned by the founding of the NO because Pirow had made no attempt to forward any national-socialist ideas during the discussions to formulate the HNP's policies. ${ }^{86}$ This is borne out by documents on his negotiations with the NP on behalf of Hertzog in January 1940. They do not include a single reference to national-socialist ideals. ${ }^{87}$ To Malan, Strijdom and Verwoerd it was blatantly obvious that Pirow had only converted to national-socialism when Germany had begun to take the upper hand in the war. Especially Strijdom was disgusted that virtually overnight Pirow had embraced the very policies that he had hounded the NP for between 1933 and 1939,88 and that he had suddenly revealed himself as a selfavowed anti-Semite. ${ }^{89}$ For Geyer, the NO was a pathetic, last-gasp gamble by Pirow, a

82. Die Nuwe Orde, 30 May 1946.

83. L. Egeland, Bridges of Understanding (Human \& Rousseau, Cape Town, 1977), p 104.

84. Shain, A Perfect Storm, pp 251-252.

85. Rand Daily Mail, 14 January 1941.

86. Die Transvaler, 11 August 1941.

87. University of Stellenbosch (hereafter US), D.F. Malan Collection, 1/1/1629, Negotiations on what a republic should entail, January 1940.

88. NA Pretoria, J.G. Strijdom Papers, Vol. 52, Strijdom - C.R. Swart, 7 December 1940.

89. G. Shimoni, Jews and Zionism: The South African Experience (1910-1967) (OUP, Cape Town, 1980), p 130. 
gamble on a German military victory and the hope that Hitler would appoint him as South Africa's ruler. ${ }^{90}$ This was a view that Verwoerd shared - and he proclaimed this loudly in Die Transvaler. ${ }^{91}$ For his part, Pirow strenuously denied the accusation of opportunism and that the success of the NO depended on a German victory. But when Ben Schoeman, a close friend and ally, asked him in private what he would do if Germany should lose the war, he retorted with a smile, "Then I am going to my farm [translated]". ${ }^{92}$ That his national-socialism was opportunistic was emphasised in the rueful confession he made shortly before his death to Horace Flather, former editor of the Natal Daily News:

If only I had the moral fortitude of Smuts I should have gone with him instead of with Hertzog. What a difference it would have meant to my political life. But I had seen the Nazi might, talked to Hitler and some of his leaders, and I was convinced that they were irresistible. Well, they weren't. And that's the way it is - the bounce of the ball.93

Pirow's burning political ambition was also reflected in his refusal to follow Hertzog into the political wilderness. On 6 November 1940 Hertzog walked out of the HNP when the party's Orange Free State conference rejected his objections to a republican system which would reduce English-speakers to second-class citizens. Hertzog confidently predicted that Pirow, who was not present, would follow him out of the party. ${ }^{94}$ A striking aspect of this break was that all those with a personal attachment to Hertzog stayed loyal to him. Senator W.J.C. Brebner and Klasie Havenga even followed Hertzog's example by resigning from parliament on 12 December 1940. Havenga formed the Afrikaner Party (AP) on 30 January 1941 to keep the legacy of Hertzog alive. However, Pirow remained in the HNP. What Hertzog did not realise was that he had become a more radical republican than many former purifieds. A disgusted Geyer viewed him as one of the self-seeking demagogues in the HNP, embracing the ideals of an exclusively Afrikaner republic while alienating Englishspeakers. ${ }^{95}$ Pirow justified his decision to remain in the HNP by claiming that he remained a Hertzog admirer, but that Afrikaner unity was so sacred to him that he had decided to stay in the HNP. He vowed that he would follow Malan with the same loyalty as he did with Hertzog. In January 1941, at the first parliamentary caucus meeting of the new parliamentary session, he proposed Malan as the new party leader. ${ }^{96}$

Malan was not about to fall to Pirow's charm offensive because he viewed him and the NO as a threat to the HNP. ${ }^{97}$ Strijdom and Verwoerd were just as determined

90. WCPA, A.L. Geyer Collection, vol. 3, Political notebook, 23 May 1941.

91. Die Transvaler, 1 August 1941

92. Schoeman, My Lewe in die Politiek, p 82.

93. H. Flather, The Way of an Editor (Purnell, Cape Town, 1977), p 10.

94. Die Transvaler, 7 November 1940.

95. WCPA, A. L. Geyer Collection, vol. 3, Political notebook, 27 December 1940.

96. Die Burger, 30 January 1941.

97. D.F. Malan, Afrikaner Volkseenheid en my Ervarings op die Pad Daarheen (Nasionale Boekhandel, Cape Town, 1959), p 190. 
not to allow Pirow to use the HNP for his own ambitions, and took the battle to him by articulating the notion of national-socialist dictatorship as alien to the national character of the Afrikaner. ${ }^{98}$ Malan's showdown with Pirow came at the Transvaal congress of the HNP on 12 August 1941. In his opening speech he attacked Pirow vehemently for being responsible for group formation and disunity in the party. Strijdom then proposed a motion that members of the HNP not be permitted to propagate any policies other than those of the party. Of the 600 delegates at the congress only 20 voted against the Strijdom motion. ${ }^{99}$ The Transvaal congress was a fatal blow for Pirow, exposing that the NO, apart from a few MPs, had no support base. The organisation was mocked as "collection of generals without an army". 100 Ultimately his reputation as an opportunist doomed him in the eyes of most Afrikaners. J.H. Theron summed up this attitude when he pointed out in a letter to Otto du Plessis, editor of Die Oosterlig, that if the war had not broken out in 1939, Pirow would still have been in the cabinet with Smuts, keeping his distance from Afrikaner nationalists in the political wilderness. ${ }^{101}$

In January 1942 Pirow announced that the sixteen NO MPs would not attend the HNP caucus meetings; they would act as an independent parliamentary group. ${ }^{102}$ They subsequently resigned from the party. Pirow still had the hope of a military victory by Nazi Germany. In South Africa, with an international order dominated by Hitler and national-socialism, he would be in a position of strength as leader of the NO. However, by 1943 it was obvious that his gamble on a Nazi victory had failed with the catastrophic destruction of the German Sixth Army at Stalingrad, and the growing military involvement of the United States in the war. Germany's defeat seemed inevitable. This meant the end of his political career, and he announced that the NO would not contest the 1943 general election. The British high commissioner's despatch to London at the end of the parliamentary session reflected how Pirow had been reduced to a pitiful figure:

He is now an embittered and frustrated lawyer politician, whose gamble on a German victory has led him to disaster. ... Even his personal appearance has changed. Instead of the rather cocky Mr Pirow of pre-war years an older shrunken figure, resembling a hunted fox, haunts the lobbies and dining rooms of the House of Assembly. ${ }^{103}$

After 1943, Pirow was permanently trapped in the political wilderness. He made numerous attempts to reconcile with the HNP leadership, dropping his adherence to national-socialism and his anti-Semitism, but to no avail. Viewing him as beyond the pale, Malan, Strijdom and Verwoerd as successive prime ministers between 1948 and

98. Basson, J.G. Strijdom, pp 362-363, 366.

99. Die Transvaler, 13 Augustus 1941; Die Volksblad, 13 August 1941.

100. M. Roberts and A. Trollip, The South African Opposition, 1939-1945. An Essay in Contemporary History (Longmans, Green \& Co, Cape Town, 1947), p 147.

101. UFS ACA, J.H.O. du Plessis Collection, J.H. Theron - O. du Plessis, 13 August 1941.

102. US, D.F. Malan Collection, 1/1/1945, Pirow - Malan, 14 January 1942.

103. NA Kew, DO 35/111p, File G581/18, High Commissioner's despatch, 4 June 1943. 
1958, kept him isolated. In 1958 the government, desperate to secure convictions in the Treason Trial, appointed him as the lead prosecutor. Pirow died during the trial on 11 October 1959. His death caused hardly a ripple in Afrikanerdom. With Verwoerd as prime minister he remained unforgiven for his opportunism. Die Transvaler, still seen as his newspaper, mentioned Pirow's death merely in passing.

Pirow was a man of many qualities, but they were all marred by his lack of deeply held principles. Winning, and the advancement of his career, was the primary goal of his politics. Geyer as the editor of Die Burger was a shrewd political observer, and was spot on when he described Pirow as a person consumed with ambition and that he was in politics to advance his own interests. Ultimately the essence of his political belief was not national-socialism; his ambition on a grand scale was to become prime minister. Pirow's founding of the NO was a gamble that went for broke, and failed. It was said of President Lyndon B. Johnson of the United States that he "was a man whose ambition could overcome almost any obstacle, save the course of history. History was moving simply too fast". 104 The same can be said of Pirow's political career.

\section{REFERENCES}

Basson, J.L., J.G. Strijdom: Sy Politieke Loopbaan van 1929 tot 1948 (Wonderboomuitgewers, Pretoria, 1980).

Bellwood, W.A., South African Backdrop (Nasionale Boekhandel, Cape Town, 1969).

Beyers, C.J. and Basson, J.L., Dictionary of South African Biography, Vol. V (Human Sciences Research Council, Pretoria, 1987).

Blackwell, L., African Occasions: Reminiscences of Thirty Years of Bar, Bench, and Politics in South Africa (Hutchinson \& Co, London, 1938).

Bresler, C.P., Lineage of Conflict: A South African Miscellany (Afrikaanse Pers Boeke, Johannesburg, 1952).

Brits, J.P., "Tielman Roos se Rol in die Suid-Afrikaanse Politiek, 1907-1935" (Unpublished D. Phil thesis, Unisa, 1977).

Brits, J., Tielman Roos: Political Prophet or Opportunist? (Unisa Press, Pretoria, 1987).

Calpin, G.H., There are No South Africans (Thomson Nelson \& Sons, London, 1941).

Darman, J., Landslide: LBJ and Ronald Reagan at the Dawn of a New America (Google Books, New York, 2015).

De Villiers, D. and J., Paul Sauer (Tafelberg, Cape Town, 1977).

Egeland, L., Bridges of Understanding (Human \& Rousseau, Cape Town, 1977).

Flather, H., The Way of an Editor (Purnell, Cape Town, 1977).

Furlong, P., Between Crown and Swastika: The Impact of the Radical Right on the Afrikaner Nationalist Movement in the Fascist Era (University of the Witwatersrand Press, Johannesburg, 1991).

Korf, L., "D.F. Malan: A Political Biography" (Unpublished D. Phil thesis, University of Stellenbosch, 2010).

104. J. Darman, Landslide: LBJ and Ronald Reagan at the Dawn of a New America (Google Books, New York, 2015), p 355. 
Le Roux, J.H. en Coetzer, P.W., Die Nasionale Party, Vol 3, Die Eerste Bewindsjare, 1924-1934 (INEG, Bloemfontein, 1982).

Long, B.K., In Smuts's Camp (OUP, London, 1945).

Malan, D.F., Afrikaner Volkseenheid en my Ervarings op die Pad Daarheen (Nasionale Boekhandel, Cape Town, 1959).

Marx, C., Oxwagon Sentinel: Radical Afrikaner Nationalism and the History of the Ossewabrandwag (Unisa Press, Pretoria, 2008).

Matthew, H.C.G., Harrison, B., Oxford Dictionary National Biography, Vol. 44 (Oxford University Press, Oxford, 2004).

Meiring, P., Tien Politieke Leiers: Manne na aan Ons Premiers (Tafelberg, Cape Town, 1973).

Ovendale, R., "Appeasement" and the English-speaking World: Britain, the United States, the Dominions and the Policy of "Appeasement", 1937-1939 (University of Wales Press, Cardiff, 1975).

Pirow, O., James Barry Munnik Hertzog (George Allen \& Unwin, London, 1957).

Pirow, O., "Drie Manne uit die Dae van Samesmelting: Hetzog, Smuts en Tielman Roos", Die Huisgenoot, 5 December 1952.

Reitz, H., The Conversion of a South African Nationalist (Unie-Volkspers, Cape Town, 1946).

Roberts, M. and Trollip, A., The South African Opposition, 1939-1945: An Essay in Contemporary History (Longmans, Green \& Co, Cape Town, 1947).

Schoeman, B., My Lewe in die Politiek (Perskor, Johannesburg, 1978).

Shain, M., A Perfect Storm: Antisemitism in South Africa, 1930-1948 (Jonathan Ball, Johannesburg, 2015).

Shimoni, G., Jews and Zionism: The South African Experience (1910-1967) (OUP, Cape Town, 1980).

Van der Byl, P., Top Hat to Velskoen (Howard Timmins, Cape Town, 1973).

Van Heerden, F.J., "Nasionaal-sosialisme as Faktor in die Suid-Afrikaanse Politiek, 1933-1948" (Unpublished D. Phil thesis, University of the Orange Free State, 1972).

Van Wyk, A., Vyf Dae. Oorlogskrisis in 1939: 'n Spanningsverhaal uit SA se Geskiedenis (Tafelberg, Cape Town, 1985).

Van der Merwe, W., “Suid-Afrika en 'Appeasement': Oswald Pirow se 'Vredesending' na Nazi-Duitsland in November 1938", Kleio, 20, 1988. 